\section{ECONOMICS}

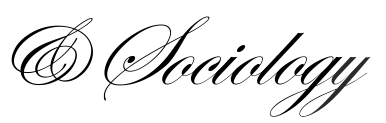

Fernández Puente, A. C., \& Sánchez-Sánchez, N. (2021). Understanding executive women's perspectives on job satisfaction and their different domains. Economics and Sociology, 14(1), 159-177. doi:10.14254/2071-789X.2021/14-1/11

\title{
UNDERSTANDING EXECUTIVE WOMEN'S PERSPECTIVES ON JOB SATISFACTION AND THEIR DIFFERENT DOMAINS
}

\author{
Adolfo C. Fernández Puente \\ University of Cantabria, \\ Santander, Spain \\ E-mail: \\ adolfocosme.fernander@unican.es \\ ORCID 0000-0003-4739-337 \\ Nuria Sánchez-Sánchez \\ University of Cantabria, \\ Santander, Spain \\ E-mail:sanchern@unican.es \\ ORCID 0000-0001-7041-4768
}

Received: March, 2020
1st Revision: July, 2020
Accepted: February, 2021

DOI: $10.14254 / 2071-$

789X.2021/14-1/11

JEL Classification: J01, J16,

\begin{abstract}
This paper studies gender differences in job satisfaction considering job rank (managers, selfemployed and employees) using the Spanish Quality of Life Survey (SQLS) for Spain throughout the period 2006-2010 and the sixth European Working Conditions Survey (EWCS) prepared in 2015, to test if the so-called "paradox of female contented worker" will extend to all ranked positions. Differences in job satisfaction by gender and job rank are analysed at an aggregated level and in terms of satisfaction with salary, promotion prospects, working hours, flexibility, stability, stress and work environment. Econometric estimations, using ordinary least squares method, are carried out and the results show that being a woman increases job satisfaction at an aggregated level. Occupying higher rank positions and being self-employed also increases job satisfaction. However, interactions for females between high and lowlevel managerial positions have a significant negative influence on job satisfaction. This interaction especially penalizes satisfaction in terms of promotion, working hours, work flexibility and stability.
\end{abstract}

Keywords: manager position, self-employed, job satisfaction, female employment.

\section{Introduction}

During the last decades, numerous studies have tried to identify job satisfaction determinants and the differences between types of workers and organizations. One of the most striking results of these studies is higher job satisfaction reported by female workers as compared to that of male workers. This result is somehow paradoxical as their working conditions, especially in terms of promotion prospects and wages, are on average considerably lower than those of their male colleagues. This outcome is known in economic literature as the paradox of the contented female worker (Crosby, 1982).

The economic literature has tried, on the one hand, to contrast this result, including in the econometric estimations the variables that could affect satisfaction, both labour and nonlabour related, whether objective or subjective. In this way, it would be feasible to observe if non-strictly labour aspects could affect job satisfaction. On the other hand, the collective of working women has been segregated attending to different criteria to observe if results were 
homogeneous within each subgroup. In this sense, most of the studies use as criteria: age, education and the economic sector in which workers are included. There are, however, few studies examining gender differences in job satisfaction considering job rank (managers, selfemployed and employees). This scarcity is especially remarkable at the managerial level. Managerial positions are frequently associated with higher pay and prestige than that of regular employees. However, they usually involve greater responsibility and workload. This trade-off between money/prestige and time/responsibility may cause the relationship between managerial positions and job satisfaction being not so straightforward, especially when different domains of job satisfaction are considered. It is possible that the perception of this trade-off differs depending on the worker considered and it will also be possible, as indicated by economic and sociological literature, that the perception would differ depending on the gender of an employee (Becker, 1991; Estévez-Abe, 2006; Glauber, 2011; Mandel and Semyonov, 2006) . In fact, it is likely that the so-called "paradox of female contented workers" will not be extended to all rank positions.

The present study aims, specifically, to fill this gap, using the Spanish Quality of Life Survey (SQLS) for Spain throughout the period 2006-2010 and the European Working Conditions Survey (EWCS) prepared in 2015. In the first place, differences in job satisfaction by gender at the aggregate level are analysed. Subsequently, the existing differences are observed by job rank, taking into consideration the distribution by gender in each rank. Differences by gender are also considered in terms of satisfaction with salary, promotion, working hours, flexibility, stability, stress and work environment to observe if any peculiarity in each domain exists. Finally, econometric estimations are carried out considering job satisfaction as the dependent variable. Determinants, among others, will be gender (female), the job rank and the interactions between job rank and gender. Estimates are made, additionally, using as the dependent variables job satisfaction with salary, promotion, working hours, flexibility, stability, job stress and job environment.

The econometric results show that women experience higher job satisfaction at an aggregated level as compared to that of men. Occupying higher-ranking positions and being self-employed also increases job satisfaction as compared to that of regular employees. However, interactions between high- and low-ranking managers and the variable of female gender have a significant negative influence on job satisfaction. This interaction especially penalizes satisfaction in terms of promotion, working hours, work flexibility and stability.

The structure of the work is as follows. In the second section, various studies that consider differences in job satisfaction by gender are analysed. In the third section, data and descriptive results are presented. Finally, in the third and fourth sections the multivariate analysis and the conclusions are included.

\section{Literature review}

The economic literature devoted to job satisfaction determinants has been extensive in the last two decades. The reason is no other than the impact of this variable on worker and organizational performance and individual well-being (Cannas et al., 2019).

One of the issues that has awoken the most interest has been the existence of differences in job satisfaction between men and women. Although the studies have shown mixed results, most of them conclude that women's job satisfaction is higher than that of men (Agassi, 1982; Clark, 1997; Crosby, 1982; Donohue \& Heywood, 2004; Long, 2005; Sloane \& Williams, 2000; and Souza-Poza \& Sousa-Poza, 2000a and 2007). This higher satisfaction rate is paradoxical, since the study of working conditions in terms of wage gap and employment segregation shows a clearly unfavourable situation for women (Duncan \& Corcoran, 1984; 
England \& McCreary, 1987; and Madden, 1985, among others), which does not seem to imply penalization in terms of job satisfaction. This has come to be known as the paradox of the contented female worker (Crosby, 1982) ${ }^{1}$.

Some studies consider these differences should be viewed as transitory when younger people with higher qualifications are considered. Econometric evidence, again, is mixed. Clark (1997), Donohue and Heywood (2004) and Sousa-Poza and Sousa-Poza (2010) conclude that gender differences disappear for younger people and those with a higher educational level. However, Bender and Heywood (2006) point out that, even at higher educational levels, women are more satisfied than their male colleagues are. In fact, in the case of Spain, Sánchez-Sánchez and Fernández $(2019,2020)$ show that job satisfaction for younger and more educated women is still higher than that of their male colleagues.

There is also a field in literature that would focus on job satisfaction differences by job rank. In principle, job satisfaction for the self-employed is higher than that of regular employees (Bianchi, 2012; Blanchflower, 2000; Blanchflorwer \& Oswald, 1998; Schneck, 2014). The reasons that justify this greater satisfaction are diverse. Hundley (2001) and more recently Schneck (2014) attributes this higher job satisfaction to increased flexibility at work, greater autonomy and job security. In fact, Binder and Coad (2016) find out that the voluntary selfemployed are not just more satisfied at work but in life.

Managerial positions should also lead to greater job satisfaction (Lup, 2017; SánchezSánchez \& Ahn, 2018) but results are not so straightforward. Low- and high-level managers have higher salaries, greater opportunities for promotion and acquire greater social prestige and recognition. However, responsibility, stress and working hours are also increased. Additionally, labour relations are also more hierarchical among managers, which will affect workplace climate and will influence job satisfaction.

Studies have found that male workers prefer jobs with high income, responsibility, autonomy, self-efficacy and opportunities for leadership. In contrast, female workers prefer jobs with good co-workers, good supervisors, in which they have the opportunity to help others and the possibility to balance work and life (Linz \& Semykina, 2013; Skalli et al., 2008; Borra et al., 2007; Bender et al., 2005; Konrad et al., 2000; Pinquart \& Sörensen, 2000, Scandura \& Lankau, 1997; Sloane \& Williams, 2000). It is feasible, therefore, that the assessment made by women would be different from that of men, especially in executive positions. In fact, social norms (often gendered) and biological characteristics may be conditioning factors that lead to women being selected for leadership positions differently to men. It is likely, thus, that the paradox of the contented female worker does not extend to business executives.

From this perspective, Brokman (2010), Trzchinski and Holst (2011) and Valentine (2002) point out that, unlike men, women's job satisfaction does not increase on occupying executive positions. Brockmann et al. (2018), in fact, point out that women with managerial careers are significantly less satisfied than their male counterparts are. They observe that women's terminated fertility has a negative impact on their levels of job satisfaction between the ages of 35 and 45, when managerial careers usually take off. Slow advancement, the glass ceiling, sexual harassment and other forms of gender discrimination could also erode women's authority and position in many organizations (Booker, 1998; Cooper, 1997, Daley \& Naff 1998, Gutek et al., 1996) and therefore reduce job satisfaction. In fact, Singhapakdi et al. (2014) justify lower job satisfaction of women managers through their perceived wage discrimination compared to male peers. Lup (2017) and Sarrió et al. (2002) show that perception of promotion is also different by gender due to the organizational culture, gender stereotypes and family responsibilities generally assumed by women.

\footnotetext{
${ }^{1}$ See Kim (2005), Mueller and Kim (2008) for a review of studies related to gender and job satisfaction, as well as Westover (2012) and Green et al. (2018) for more recent reviews of the paradox of the contented female worker.
} 
A longer workday could also affect job satisfaction, especially when the worker has family responsibilities (Scandura \& Lankau, 1997). Since it is women who have traditionally assumed such roles, their job satisfaction would be reduced. Cha (2013) shows that mothers are more likely to leave jobs when they work 50 hours or more per week because their time is more subject to family demands than men are. Booth and Van Ours (2013) find than women are happier with part time jobs than men because of the possibility to combine work and family care. The trade-off between money and time would therefore be different by gender.

Given that women's integration in the labour market and more specifically in managerial positions has been relatively recent and regionally disparate, it is likely that significant differences could be observed between countries depending on cultural factors, family and social organization ${ }^{2}$. In those countries where women's participation is greater, differences between female and male executives should be lower (Singhapakdi et al., 2014 ${ }^{3}$ ) Research in Spain is scarce and the conclusions, even at an aggregated level, are disparate. Alvarez (2004), Kaiser (2007), Rico (2012), Hauret and Williams ${ }^{4}$ (2017) and Sánchez-Sánchez and Fernández $(2019,2020)$ indicate that women's satisfaction is higher than men's, while Mora and Carbonell (2009) conclude that women's satisfaction is lower than their male colleagues are ${ }^{5}$. However, Sousa-Poza and Sousa-Poza (2000b) and Gamero (2004) conclude that there are not significant differences between both genders. None of the mentioned studies considers the interaction between females and job rank ${ }^{6}$.

The consideration of gender in manager positions is especially interesting in Spain. The presence of women in management and CEO positions is lower than that of men (14.3 percent of the management positions and 2.9 percent of the CEO positions in 2010 were occupied by women, according to data from the National Securities Market Commission (2018) and the European Institute for Gender Equality (2018)). The participation of women in these positions were, in fact, lower than that in Europe-28 (15.9 percent and 6.3 percent, respectively). Finally, the wage gap between men and women in the case of Spain amounts to 14 percent ( 23 percent if not adjusted for hours worked) according to INE (2010).

\section{Methodological approach}

The data for this work are extracted from the Spanish Survey of Life Quality at Work (SLQW). This survey is conducted on more than 7000 Spanish workers, starting in 1999. Our study focuses on five cross-sections of the survey for the years 2006-2010 ${ }^{7}$. The main advantage of the survey is that it includes workers' self-reported satisfaction scores in different job domains as well as overall job satisfaction, along with the information on important worker and job characteristics. Unfortunately, the survey is not longitudinal, therefore it is unable to examine the factors affecting transitions in satisfaction levels or to control fixed individual effects.

Additionally, we are using the European Working Conditions Survey (EWCS), prepared in 2015. This cross-sectional survey is organized every 5 years since 1990 by the European Foundation for the Improvement of Living and Working Conditions. This sixth survey interviewed nearly 44,000 workers in 35 countries. The data from this survey, although more

\footnotetext{
${ }^{2}$ See Perugini and Vladisavljevic (2018), Dilmaghani and Tabvuma (2019) and Fernández and Sánchez-Sánchez (2021) to justify the differences in female job satisfaction in Europe according to economic and political criteria.

${ }^{3}$ The study is focused on female job satisfaction differences between Thailand and United States.

${ }^{4}$ Spain is not analyzed separately as it is included in the group of Southern European countries.

${ }^{5}$ Their research is focused exclusively on the region of Catalonia for the case of university lecturers.

${ }^{6}$ García-Mainar et al. (2016) consider gender differences in occupations but not considering job-rank.

${ }^{7}$ Although survey data is available since 1999, there were some methodological changes which make data incomparable between pre and post 2006 periods. The survey was discontinued in 2011 as a result of government budget cuts.
} 
up to date, are only used in the descriptive analysis and to corroborate that our data are consistent over time. The number of observations for Spain is reduced. Specifically, the number of observations is 3,329 and only 1,627 observations correspond to female works. From these observations, only 217 correspond to female self-employed and 34 to managers. Additionally, the survey does not distinguish between high and low managers and between self-employed with and without employees. For this reason, econometric estimates cannot be carried out consistently.

At the outset, it is important to understand the satisfaction questions we analyse. The respondents in the survey were asked "How satisfied are you with your job (or different job aspects)?" with 10 possible response categories ranging from 'very dissatisfied' $(=1)$ to 'very satisfied' (=10). The responses are based entirely on individuals' own perception. The question asked is not concrete in terms of comparison groups or in the description of each category of satisfaction levels ${ }^{8}$, therefore leaving a large room for interpretation heterogeneity across interviewees. Another characteristic to note is that the responses are ordered qualitatively ${ }^{9}$. Comparing the responses between groups of people is not straightforward. We begin with simple "averages" of the responses. The simple average provides a satisfaction index, which is comparable across year or population under the assumption of linearity across response category.

In this paper we do not use exclusively a single measure of job satisfaction but multipleitems measures. Thus, apart from the aggregate job satisfaction, satisfaction with wage, promotion, work hours, flexibility, stability, environment and stress ${ }^{10}$. Job satisfaction with these domains also corresponds to the subjective perception of the interviewee and is measured in the same way as the aggregate job satisfaction. In the case of the last item, individuals were asked to indicate the level of stress they were suffering, ranging from 1 (minimum) to 10 (maximum).

\section{Conducting research and results}

\subsection{Descriptive analysis}

Table 1 reports average job satisfaction and the distribution of workers by worker and job characteristics by gender. As can be observed, there are considerable differences in the proportion of men and women in the different job ranks. It is particularly noteworthy the scarcity of women among higher executive positions (5\% of all women workers compared to $9 \%$ of me workers) and low manager positions (12\% versus $19 \%$ ). We could think that there could be a certain correspondence between education and job rank, however the proportion of men without education is much higher than that of women. Likewise, the proportion of women with university studies is higher than that of men. The proportion of self-employed women is also smaller than that of men ( $8 \%$ versus $13 \%)$.

\footnotetext{
${ }^{8}$ The categories $(2,3,4, \ldots, 9)$ between the worst $(=1)$ and the best $(=10)$ have no words attached to them.

${ }^{9}$ To the extent that respondents considered the response numbers (1 to 10) as cardinal measures of their satisfaction (for example, the response 10 means twice more satisfied than the response 5) the reported values may be used as a cardinal measure of satisfaction. However, qualitative differences in empirical results between different treatments of the variable are virtually non-existent.

${ }^{10}$ The election of variables was conditioned by the availability of data in the survey but also by the consideration of those aspects in which working in managerial positions could make a difference.
} 
Table 1. Mean Job Satisfaction and Distribution by job rank and education

\begin{tabular}{|c|c|c|c|c|c|c|}
\hline & \multicolumn{2}{|c|}{ Total } & \multicolumn{2}{|c|}{ Female } & \multicolumn{2}{|c|}{ Male } \\
\hline & Dist. & Job & Dist. & Job & Dist. & Job \\
\hline & & Sat. & & Sat. & & Sat. \\
\hline All & 1.00 & 7.32 & 1.00 & 7.32 & 1.00 & 7.28 \\
\hline \multicolumn{7}{|l|}{ By job rank/type } \\
\hline Employee & 0.65 & 7.20 & 0.75 & 7.25 & 0.60 & 7.15 \\
\hline Low manager & 0.18 & 7.57 & 0.12 & 7.57 & 0.19 & 7.54 \\
\hline High manager & 0.08 & 7.87 & 0.05 & 7.73 & 0.09 & 7.82 \\
\hline Self-employed with employees & 0.00 & 7.83 & 0.00 & 7.95 & 0.01 & 7.67 \\
\hline Self-employed without employees & 0.09 & 7.23 & 0.08 & 7.12 & 0.12 & 7.11 \\
\hline \multicolumn{7}{|l|}{ By education } \\
\hline No education & 0.03 & 7.21 & 0.03 & 6.94 & 0.38 & 7.13 \\
\hline Primary & 0.16 & 7.19 & 0.27 & 7.17 & 0.10 & 7.21 \\
\hline Secondary & 0.21 & 7.34 & 0.19 & 7.27 & 0.23 & 7.22 \\
\hline 2 year college & 0.35 & 7.27 & 0.34 & 7.29 & 0.34 & 7.27 \\
\hline University & 0.26 & 7.46 & 0.32 & 7.41 & 0.20 & 7.46 \\
\hline
\end{tabular}

Source: own calculation

There are also differences in job satisfaction by gender ${ }^{11}$. Overall job satisfaction is higher for women than men (7.32 and 7.28, respectively). By sector and contract type, job satisfaction is always higher among the workers with a permanent contract and in the public sector but the differences by gender are not very remarkable. Managerial workers always report higher job satisfaction than ordinary employees. Job satisfaction is higher among self-employed with employees, followed by high managers, low managers, employees and self-employed without employees, respectively.

By gender, it is noteworthy the difference in favour of women among employees and self-employed with employees ${ }^{12}$ and, what is more relevant for our purpose, female high managers are less satisfied than men at work. The differences in low manager positions are not remarkable.

The data from the EWCS can not be compared with those of our survey, as it does not distinguish between high and low managers and between self-employed with and without employees. In any case, it can be corroborated that the participation of women in executive positions is smaller than that of men and job satisfaction slightly higher. Additionally, the aggregate data show that job satisfaction of managers and self-employed is higher than that of employees. The data also reflect a different pattern by gender in the different positions (differences more remarkable among managers).

\section{Job Domain Satisfaction}

It seems clear that female job satisfaction does not follow the same pattern as that of males in the different job ranks. This is especially true between higher-level managers, where female executives experience lower job satisfaction than male executives. That is why a disaggregated analysis is proposed to identify which job domains are especially penalised by female executives. From this perspective, overall job satisfaction can be considered as a combined (weighted average) evaluation by workers of several different job aspects. Workers' perceived satisfaction in some job domains may be higher than in others. Then, we contrast average satisfaction scores in different job aspects (wage, promotion, work hours, time flexibility, stability, stress at work, and environment) by gender (Table 2).

\footnotetext{
${ }^{11}$ Note that comparisons have to be made with caution because male and female worker groups are homogenous respecting to age, education, sector/contract or job rank, but may differ in the rest of the characteristics of their jobs.

${ }^{12}$ Note that the proportion of self-employed with employees is small, especially among women.
} 
RECENT ISSUES IN SOCIOLOGICAL RESEARCH

Table 2. Mean Satisfaction Scores in Different Job Aspects

\begin{tabular}{|c|c|c|c|}
\hline & Total & Female & Male \\
\hline Wage & 6.00 & 5.91 & 6.07 \\
\hline \multicolumn{4}{|l|}{ By job rank/type } \\
\hline Employee & 5.90 & 5.87 & 5.93 \\
\hline Self-employed without employees & 5.48 & 5.23 & 5.62 \\
\hline Self-employed with employees & 6.37 & 6.66 & 6.28 \\
\hline Low manager & 6.50 & 6.44 & 6.52 \\
\hline High manager & 6.56 & 6.38 & 6.62 \\
\hline Time flexibility & 6.44 & 6.39 & 6.47 \\
\hline \multicolumn{4}{|l|}{ By job rank/type } \\
\hline Employee & 6.20 & 6.25 & 6.15 \\
\hline Self-employed without & 7.03 & 6.93 & 7.08 \\
\hline Self-employed with & 7.25 & 7.00 & 7.33 \\
\hline Low manager & 6.68 & 6.62 & 6.70 \\
\hline High manager & 7.24 & 7.00 & 7.33 \\
\hline Promotion & 5.04 & 4.74 & 5.25 \\
\hline \multicolumn{4}{|l|}{ By job rank/type } \\
\hline Employee & 4.75 & 4.56 & 4.92 \\
\hline Self-employed without & 5.37 & 4.86 & 5.67 \\
\hline Self-employed with & 6.12 & 6.30 & 6.05 \\
\hline Low manager & 5.90 & 5.67 & 5.99 \\
\hline High manager & 6.53 & 6.10 & 6.66 \\
\hline Work hours & 7.03 & 7.15 & 6.94 \\
\hline \multicolumn{4}{|l|}{ By job rank/type } \\
\hline Employee & 7.11 & 7.23 & 7.00 \\
\hline Self-employed without & 6.52 & 6.56 & 6.50 \\
\hline Self-employed with & 6.92 & 6.82 & 6.96 \\
\hline Low manager & 7.11 & 7.20 & 7.07 \\
\hline High manager & 6.88 & 6.87 & 6.89 \\
\hline Stability & 7.27 & 7.29 & 7.25 \\
\hline \multicolumn{4}{|l|}{ By job rank/type } \\
\hline Employee & 7.22 & 7.28 & 7.17 \\
\hline Self-employed without & 6.33 & 6.30 & 6.34 \\
\hline Self-employed with & 7.37 & 7.43 & 7.35 \\
\hline Low manager & 7.93 & 7.97 & 7.91 \\
\hline High manager & 7.55 & 7.42 & 7.60 \\
\hline Stress at job & 5.62 & 5.73 & 5.54 \\
\hline \multicolumn{4}{|l|}{ By job rank/type } \\
\hline Employee & 5.32 & 5.50 & 5.11 \\
\hline Self-employed without & 5.60 & 5.56 & 5.62 \\
\hline Self-employed with & 6.40 & 6.36 & 6.41 \\
\hline Low manager & 6.40 & 6.69 & 6.26 \\
\hline High manager & 6.72 & 6.67 & 6.74 \\
\hline Environment & 7.81 & 7.84 & 7.79 \\
\hline \multicolumn{4}{|l|}{ By job rank/type } \\
\hline Employee & 7.74 & 7.81 & 7.68 \\
\hline Self-employed without & 7.67 & 7.87 & 7.58 \\
\hline Self-employed with & 7.76 & 7.5 & 7.83 \\
\hline Low manager & 7.87 & 7.75 & 7.92 \\
\hline High manager & 8.46 & 8.67 & 8.38 \\
\hline
\end{tabular}

Source: own calculation

Women, at an aggregate level, are less satisfied than men with respect to wage, promotion prospects and time flexibility. However, they seem to be more satisfied in terms of work hours, stability, stress at work and job environment. These results could not be generalised 
to all job ranks, as differences are remarkable. In the case of employees, women are, at an aggregate level, more satisfied than men are in all domains, except for satisfaction with salary and promotion. However, when higher job ranks are considered the number of domains in which women are more satisfied than men are reduced. Among the self-employed without employees, satisfaction is only superior with regards work-hours and environment. While for the self-employed with salaried employees, stability, and promotion. Among low-level managers, job satisfaction is greater regarding stability, stress and work hours. Finally, and more striking, job satisfaction reported by high-level female managers is always lower than that of male managers in all domains considered, except work-place environment.

Table 3 shows the previous results in a more noticeable way. The shaded cells are those in which women's job satisfaction is lower than that of men. As can be observed, as higher job ranks are considered the number of shaded cells increases. The comparisons between high managers and regular employees are especially striking. These results allow us to conjecture, preliminarily, why women are less satisfied than men in this rank position, a penalty in terms of time flexibility stability, stress at work and work hours, added to that of wage and promotion suffered by the female employees.

It is also, noteworthy the case of the self-employed with employees, where there seems to be a specific pattern. It should not be forgotten, in any case, that the proportion of women in this category is very small.

Table 3. Satisfaction in different job domains

\begin{tabular}{|c|c|c|c|c|c|c|}
\hline & Employee & $\begin{array}{c}\text { Self- } \\
\text { employed } \\
\text { without } \\
\text { employees }\end{array}$ & $\begin{array}{c}\text { Self- } \\
\text { employed } \\
\text { with } \\
\text { employees }\end{array}$ & $\begin{array}{l}\text { Low } \\
\text { manager }\end{array}$ & $\begin{array}{l}\text { High } \\
\text { manager }\end{array}$ & Total \\
\hline \multicolumn{7}{|l|}{ Wage } \\
\hline \multicolumn{7}{|l|}{ Time flexibility } \\
\hline \multicolumn{7}{|l|}{ Stability } \\
\hline \multicolumn{7}{|l|}{ Stress at job } \\
\hline \multicolumn{7}{|l|}{ Work hours } \\
\hline \multicolumn{7}{|l|}{ Promotion } \\
\hline Environment & & & & & & \\
\hline
\end{tabular}

Source: own calculation

\subsection{Multivariate analysis}

The descriptive results in the previous section seem reasonable but they are likely to be biased due to confounding effects of other correlated characteristics. To establish the net effects of other correlated variables we run regressions including many relevant variables available in our data. We have estimated using an ordinary least squared (OLS) method. While ordered probit (or logit) estimation which respects the qualitative nature of the response options is theoretically more preferable, the results were very similar to those of the OLS model, and therefore we decided to present OLS results for its simplicity in interpretation ${ }^{13}$.

We have included as independent variables worker and job characteristics such as female, age, education, partner occupation, wage, job tenure, job rank and region. Given the interesting difference between female and male workers in job satisfaction by job rank/type, as

\footnotetext{
${ }^{13}$ See Ferrer-i-Carbonell and Frijters (2004) for a more detailed discussion on different estimation methods and the similarity in their results.
} 
shown in the descriptive analysis, we estimate with and without interaction terms between job rank and gender (table 4 and annex A2). The coefficients should be interpreted in relation to the omitted variable, in our case the one corresponding to regular employees.

First, let us discuss other control variables before we go on to the variables of our main interest. Age is only marginally significant. Younger and older workers (>65) are more satisfied, as pointed out by Sánchez-Sánchez and Fernández (2020). Education level is also marginally significant with negative effects for those with a university degree. Wage has a significant positive effect with more than 0.20 points higher for each additional wage category ( 4 categories in total). Permanent contracts and public sector jobs appear to give significantly higher satisfaction than temporary contracts and private sector, as pointed out by SánchezSánchez and Fernández (2020).

Table 4. OLS Estimation Results on Job Satisfaction

\begin{tabular}{|c|c|c|c|c|}
\hline & \multicolumn{2}{|c|}{ Without Interaction } & \multicolumn{2}{|c|}{ With Interactions } \\
\hline & Coef. & $\mathrm{p}$ value & Coef. & $\mathrm{p}$ value \\
\hline Female & 0.07 & 0.12 & 0.12 & 0.02 \\
\hline \multicolumn{5}{|l|}{ Job rank/type } \\
\hline Self-employed without employees & 0.11 & 0.18 & 0.11 & 0.24 \\
\hline Self-employed with employees & 0.68 & 0.00 & 0.68 & 0.00 \\
\hline Low manager & 0.25 & 0.00 & 0.33 & 0.00 \\
\hline High manager & 0.59 & 0.00 & 0.65 & 0.00 \\
\hline \multicolumn{5}{|l|}{ Female interacted with } \\
\hline Self-employed without employees & & & 0.02 & 0.89 \\
\hline Self-employed with employees & & & 0.10 & 0.87 \\
\hline Low manager & & & -0.24 & 0.01 \\
\hline High manager & & & -0.20 & 0.18 \\
\hline Adjusted $\mathrm{R}^{2}$ & 0.06 & & 0.06 & \\
\hline $\mathrm{N}$ & 18510 & & 18510 & \\
\hline
\end{tabular}

Observations are weighted using the individual weights in the SQLS.

Source: own calculation

Now, turning to the variables of main interest, we could observer that the female coefficient is positive and significant. This result is consistent with those of Agassi (1982), Clark (1997), Crosby, (1982), Donohue and Heywood (2004), Long (2005), Sloane and Williams (2000) and Souza-Poza and Sousa-Poza (2000a and 2007). Occupying higher job ranks also increases job satisfaction, especially for the self-employed with employees $(0.68$ points), followed by high managers ( 0.65 points $)$, low managers $(0.33$ points $)$ and selfemployed employees ( 0.11 points). These results are consistent with those of Blanchflower (2000), Blanchflower and Oswald (1998) and Benz and Frey (2008) and with those of SánchezSanchez and Ahn (2018) and Lup (2017).

The results support, on the one hand, greater job satisfaction for women and, on the other, of higher managerial positions, but what happens then with those women occupying superior ranked positions? As can be observed in the estimates with interaction, the coefficient of women is positive (0.12) and significant, however, the interaction between this coefficient and occupying managerial positions has a negative impact on total satisfaction $(-0.20$ for high manager, but not highly significant, and -0.24 for low manager interacted with female). In the case of the self-employed the coefficients are positive, though not significant. In any the case, the results show that the paradox of the contented female worker does not extend to all rank positions. The penalty is therefore negative in the case of low managers (we should not forget that this category is more frequent than that of high manager in the case of women). 
To examine this result in overall job satisfaction further, we run regressions on the satisfaction related to different job aspects with interaction terms between gender and job rank. Different domains are grouped into three categories: i) wage and promotion (table 5), referring to present and future income possibilities; ii) work hours and flexibility (table 6), referring to the workload and the possibility to make work and personal life compatible; and iii) stability, stress and the work-place environment (table 7) referring to other aspects of the work that could affect total job satisfaction ${ }^{14}$.

\section{Satisfaction with Wage and promotion:}

While high-level managers exhibit substantially higher wage satisfaction than regular employees, the self-employed have lost their premium (the coefficient is positive for the selfemployed with employees but not significant). Women, at an aggregated level, are more satisfied than men are with wages. Meanwhile, interactions between managers, both high and low, and female are negative and significant. This result could be justified, as pointed out by Singhapakdi et al. (2014), by the perceived female wage discrimination in relation to their male peers ${ }^{15}$. The interaction between the self-employed with employees and female is positive but between self-employed without employees is negative.

Satisfaction with promotion is highest among high-level managers and the selfemployed and lowest among ordinary employees. Female coefficient is negative and significant, in contrast with the results of Lup (2017) and Sarrio et al. (2002). There also exists an additional penalty if the interaction with job rank is considered. The interaction between low manager and female is especially noteworthy. It is logical, in any case, that satisfaction with promotion will be lower among low-level managers than among the high ones, since the latter have already reached the highest positions. The existence of a glass-ceiling that difficulties the access of women to the highest managerial positions could cause the reduction in job satisfaction with promotion (Rica et al., 2005).

Table 5. OLS Estimation of Satisfaction with wage and promotion

\begin{tabular}{|c|c|c|c|c|}
\hline & \multicolumn{2}{|c|}{ Wage } & \multicolumn{2}{|c|}{ Promotion } \\
\hline & Coef. & $\mathrm{p}$ value & Coef. & $\mathrm{p}$ value \\
\hline Female & 0.28 & 0.00 & -0.27 & 0.00 \\
\hline \multicolumn{5}{|l|}{ Job rank/type } \\
\hline \multicolumn{5}{|l|}{ Employee (ref) } \\
\hline High manager & 0.51 & 0.00 & 1.77 & 0.00 \\
\hline Low manager & 0.36 & 0.00 & 0.96 & 0.00 \\
\hline Self-employed with employees & 0.26 & 0.48 & 2.46 & 0.00 \\
\hline Self-employed without employees & -0.06 & 0.56 & 0.22 & 0.50 \\
\hline \multicolumn{5}{|l|}{ Female interacted with } \\
\hline "High manager & -0.33 & 0.05 & -0.11 & 0.78 \\
\hline Low manager & -0.28 & 0.02 & -0.60 & 0.04 \\
\hline Self-employed with employees & 1.15 & 0.08 & -2.53 & 0.17 \\
\hline Self-employed without employees & -0.31 & 0.07 & -0.58 & 0.31 \\
\hline Adjusted $\mathrm{R}^{2}$ & 0.10 & & 0,07 & \\
\hline $\mathbf{N}$ & 18269 & & 14910 & \\
\hline
\end{tabular}

Source: own calculation

\footnotetext{
${ }^{14}$ The complete results are found in the appendix 3.

${ }^{15}$ See Arulampalam et al. (2007) to study de evidence of gender wage gap in Spain.
} 
Satisfaction with Work hours and flexibility:

High and low-level managers and employers have higher satisfaction with work hours. Female coefficient is positive but not significant. By job rank, the interaction between low-level manager and female is negative and significant. It seems, therefore, that there could be a penalty for female managers in terms of work hours, as pointed out by Scandura and Lankau (1997), Cha (2013) and Booth and Van Ours (2013), but just for low-level positions. In the rest of job ranks considered, coefficients are not significant.

Managers, along with the self-employed have higher satisfaction with time flexibility than normal employees do. Female coefficient at an aggregated level is also negative and significant. Meanwhile, the interaction between job rank and female is not significant. Women with higher hierarchical positions do not have satisfaction gains in terms of flexibility. Results are especially significant between low-level managers and female, where the coefficient, as in the case of work hours, is negative.

Table 6. OLS Estimation of Satisfaction with work hours and flexibility

\begin{tabular}{|c|c|c|c|c|}
\hline & \multicolumn{2}{|c|}{ Work hours } & \multicolumn{2}{|c|}{ Flexibility } \\
\hline & Coef. & $\mathrm{p}$ value & Coef. & $\mathrm{p}$ value \\
\hline Female & 0,01 & 0.92 & -0.21 & 0.01 \\
\hline \multicolumn{5}{|l|}{ Job rank/type } \\
\hline \multicolumn{5}{|l|}{ Employee (ref) } \\
\hline High manager & 0.17 & 0.14 & 1.02 & 0.00 \\
\hline Low manager & 0.15 & 0.03 & 0.51 & 0.00 \\
\hline Self-employed with employees & -0.02 & 0.97 & 1.04 & 0.02 \\
\hline Self-employed without employees & 0.02 & 0.82 & 0.99 & 0.00 \\
\hline \multicolumn{5}{|l|}{ Female interacted with } \\
\hline High manager & 0.16 & 0.40 & 0.06 & 0.78 \\
\hline Low manager & -0.29 & 0.07 & 0.00 & 0.99 \\
\hline Self-employed with employees & -0.45 & 0.58 & -0.44 & 0.71 \\
\hline Self-employed without employees & 0.11 & 0.52 & -0.04 & 0.86 \\
\hline Adjusted $\mathrm{R}^{2}$ & 0,12 & & 0.05 & \\
\hline $\mathbf{N}$ & 18510 & & 18510 & \\
\hline
\end{tabular}

Source: own calculation

Satisfaction with job stability, perceived job stress and job environment

Satisfaction with job stability is lower among high-level managers and much lower among the self-employed compared with that of regular employees, above all, those selfemployed without employees. The female aggregated coefficient is, in this case, not significant. Meanwhile the interaction between manager (high and low-level) and variable female is negative while that of the self-employed is positive (it is not very significant in both cases).

Satisfaction with perceived job stress is higher among high-level managers and selfemployed and lower among ordinary employees. Female coefficient is positive and significant, which means that women suffer more stress than men at work. However, the interaction between female and the different job ranks considered is not significant.

Finally, high and low-level managers have higher satisfaction with work-place environment than regular employees do. Female coefficient is positive but not significant, in contrast to the results of Linz and Semykina (2013) and Borra et al. (20007). The interaction 
between job rank and female is exclusively positive and significant for self-employed without employees.

Table 7. OLS Estimation of Satisfaction with job stability, job stress and job environment

\begin{tabular}{|c|c|c|c|c|c|c|}
\hline & \multicolumn{2}{|c|}{ Job stability } & \multicolumn{2}{|c|}{ Job stress } & \multicolumn{2}{|c|}{ Environment } \\
\hline & Coef. & $\mathrm{p}$ value & Coef. & $\mathrm{p}$ value & Coef. & $\begin{array}{c}\mathrm{p} \\
\text { value }\end{array}$ \\
\hline Female & 0.04 & 0.57 & 0.6 & 0.00 & 0,01 & 0.94 \\
\hline \multicolumn{7}{|l|}{ Job rank/type } \\
\hline \multicolumn{7}{|l|}{ Employee (ref) } \\
\hline High manager & -0.16 & 0.17 & 0.87 & 0.00 & 0,74 & 0.00 \\
\hline Low manager & 0.29 & 0.00 & 0.61 & 0.00 & 0,26 & 0.00 \\
\hline Self-employed with employees & -0.32 & 0.42 & 0.43 & 0.38 & $-0,24$ & 0.72 \\
\hline Self-employed without employees & -1.19 & 0.00 & 0.23 & 0.09 & $-0,25$ & 0.34 \\
\hline \multicolumn{7}{|l|}{ Female interacted with } \\
\hline High manager & -0.03 & 0.86 & -0.39 & 0.08 & 0,08 & 0.72 \\
\hline Low manager & -0.48 & 0.13 & -0.13 & 0.39 & $-0,17$ & 0.27 \\
\hline Self-employed with employees & 0.36 & 0.59 & -0.23 & 0.77 & $-0,18$ & 0.46 \\
\hline Self-employed without employees & 0.26 & 0.19 & -0.20 & 0.39 & 0,78 & 0.01 \\
\hline Adjusted $\mathrm{R}^{2}$ & 0.20 & & 0.11 & & 0,04 & \\
\hline $\mathbf{N}$ & 18510 & & 18510 & & 9141 & \\
\hline
\end{tabular}

Source: own calculation

The results show, therefore, considerable differences in female coefficients among job domains. The coefficients are positive in wage and job stress, and negative in promotion and flexibility. Managers and the self-employed are generally more satisfied than regular employees are. This result could be justified by the greater satisfaction in terms of salary, promotion, work hours, flexibility and stress. However, they would be less satisfied in terms of stability and work environment. With regard to the interaction between female and job rank, there exists a penalty for high-level female managers in terms of salary and stress. In the case of low-level female managers, the penalty is observed in terms of salary, working hours and promotion, and to a lesser extent in job stability. In any case, both groups present a differentiated idiosyncrasy with respect to males occupying these positions

\section{Conclusion}

The present study analyses the differences in female job satisfaction by job rank. Economic literature has not been determinant regarding the differences in job satisfaction by gender and the possible existence of a penalty in terms of satisfaction for female managers. The study focuses on five cross-sections of the SQL survey for the years 2006-2010 that includes workers' self-reported satisfaction scores in different job domains as well as overall job satisfaction (wage, promotion, work hours, flexibility, job stability, job stress and job environment). We begin with averages of the responses to provide a satisfaction index, which is comparable across groups under the assumption of linearity across response category. Then we have made econometric estimations using ordinary least square method including worker and job characteristics. We focus our attention on female coefficient and the interaction between female and job rank. 
The descriptive analysis shows that job satisfaction reported by women is higher than that of men in all domains considered, except for in the case of high-level managers. It is also noticeable that the highest levels of female job satisfaction are found in the domains of stability and work hours. In any case, as the job rank is higher, female job satisfaction decreases in the different job domains. In fact, high-level female manager job satisfaction with respect to salary, promotion, working hours, flexibility, stability and stress is lower than that of men and is only superior with respect to work-place environment. Additionally, we compare these results with those corresponding to the sixth EWCS for Spain to observe that they are consistent over time.

Econometric estimations corroborate the descriptive analysis since the impact of the female coefficient is positive and significant on job satisfaction. There are, again, significant differences by job rank. In fact, interactions between female and high and low-level manager are negative and non-significant with the self-employed. Therefore, the highest levels of satisfaction reported by women at an aggregated level are exclusively justified by female employees.

By job domains, the interaction between female and high-level manager penalizes job satisfaction with respect to salary and job stress and does not increase job satisfaction with flexibility, stability, working hours and promotion. With regard to the interaction between female and low-level manager, it also penalizes job satisfaction with salary, stability, working hours and promotion, and does not increase job satisfaction in the other domains. The interaction between female and the self-employed without employees is only positive in terms of salary and workplace environment.

This lower level of job satisfaction among female executives, together with other issues related to employment discrimination, could be one of the elements that justified the low presence of women in managerial positions. Increasing the presence of women in these positions would imply not just anti-discrimination laws but also some type of premium to increase their satisfaction.

Finally, and regarding the limitations of the analysis, the survey does not allow for studying individual fixed effects as it is not a panel. Likewise, other rank groupings could be made among workers that could enrich the analysis and justify differences in female job satisfaction. The idiosyncrasy of self-employed workers should also be explored more deeply as the results differ considerably from those of high- and low-level managers. Future research should be focused on this field.

\section{References}

Agassi, J. B. (1982). Comparing the work attitudes of women and men. Lexington, MA, Lexington Books.

Álvarez, G. (2004). Análisis empírico de los determinantes de la satisfacción laboral en España. Revista de Economía y Empresa, 52, 105-118.

Arulampalam, W., Booth, A., \& Bryan, M. (2007). Is there a Glass Ceiling over Europe? Exploring the gender gap across the wage distribution. Industrial and Labor Relations Review, 60 (2), 163-186.

Beatty, c.A. (1996), The stress of managerial and professional women: is the price too high? Journal of Organizational Behavior, 17 (3), 233-51.

Becker G.S. (1991). A treatise on the family. Cambridge, MA: Harvard University Press.

Bender, K. A., \& Heywood, J.S. (2006). Job satisfaction of the highly educated: the role of gender, academic tenure and earnings. Scottish Journal of Political Economy, 53(2), 253279. 
Bender, K. A., Donohue, S., \& Heywood, J.S. (2005). Job satisfaction and gender segregation. Oxford Economic Paper, 57, 479-496.

Benz, M., \& Frey, B. S. (2008). The value of doing what you like: Evidence from the selfemployed in 23 countries. Journal of Economic Behavior \& Organization, 68(3-4), 445455 .

Bianchi, M. (2012). Financial development, entrepreneurship, and job satisfaction. The Review of Economics and Statistics, 94, 362-383.

Binder, M., \& Coad, A. (2016). How Satisfied Are the Self-Employed? A Life Domain View. Journal of Happiness Studies, 17(4), 1409-1433.

Blanchflower, D.G., \& Oswald, A.J. (1998). What makes an entrepreneur?. Journal of Labour Economics, 16, 26-60.

Blanchflower, D.G. (2000). Self-employment in OECD countries. Labour Economics, 7, 471505

Booker, M.J. (1998). Can sexual harassament be salvaged?. Journal of Business Ethics, 17, 1171-1177.

Booth, A. L., \& van Ours, J. C. (2013). Part-time jobs: what women want?. Journal of Population economics, 26(1), 263-283.

Borra, C., Gómez, F., \& Salas, M. (2007). Los determinantes de la satisfacción laboral de los economistas: evidencia a partir de una nueva muestra. Economic Working Papers E2007/02 at Centro de Estudios Andaluces.

Brokman, H. (2010). Why are middle-aged people so depressed? Evidence from WestGermany. Social Indicators Research, 97(1), 23-42.

Brokman, H., Koch, A.M., Diederich, A., \& Edling, C. (2017). Journal of Happiness Studies, 19, 755-779.

Cannas, M., Sergi, B. S., Sironi, E., \& Mentel, U. (2019). Job satisfaction and subjective wellbeing in Europe. Economics and Sociology, 12(4), 183-196.

Cha. (2013). Overwork and the persistence of gender segregation in occupations. Gender \& Society, 27(2), 158-184.

Clark, A.E (1997). Job satisfaction and gender: why are women so happy at work? Labour Economics, 4, 341-72.

Cooper, V.W (1997). Homophily of the Queen Bee syndrome: Female evaluation of female leathership. Small Group Research, 28, 483-499.

Crosby, F.J. (1982). Relative deprivatization and working women. New York, Oxford University Press.

Daley, D.M. and Naff, K.C. (1998). Gender differences and managerial competencies: Federal supervisor perceptions of the job of management. Review of Public Personnel Administration, 18, 41-56.

Dilmaghani, M., \& Tabvuma, V. (2019). No Rossy glasses in Bluesy Ghettos? Job satisfaction of pink and blue collar workers and the comparable worth legislations. Labor History, 60(4), 392-407.

Donohue S. M., \& Heywood J. S. (2004). Job satisfaction and gender: an expanded specification from the NLSY. International Journal of Manpower, 25(2). 211-234.

Duncan, G. J., \& Corcoran, M. (1984). Do Women 'Deserve' to Earn Less Than Men? in Years of Poverty, Years of Plenty, edited by G. Duncan, R. Coe, M. Corcoran, M. Hill, S. Hoffman, and J. Morgan, University of Michigan, Institute for Social Research: 15372.

England, P., \& McCrear, L. (1987), Gender Inequality in Paid Employment, in Analyzing Gender, edited by Beth B. Hess and M. M. Ferree, Newbury Park, CA. Sage: 286-320.

Estévez-Abe M. (2006). Gendering the varieties of capitalism. A study of occupational segregation by sex in advanced industrial countries. World Politics, 59(1), 142-75. 
Ferrer-i-Carbonell, A., \& Frijters, P. (2004). How important is methodology for the estimates of the determinants of happiness?. The Economic Journal, 114(July), 641-659.

Gamero C. (2004). Satisfacción laboral de los asalariados en España. Especial referencia a las diferencias por género. Cuadernos de Economía, 27, 109-146.

Garcia-Mainar, I., García-Martín, G., \& Montuenga, V.M. (2016). Gender differences in occupations, job attributes, and job satisfaction. Revista Economía Aplicada, 24(71), 3967.

Glauber R. (2011). Limited access: Gender, occupational com-position, and flexible work scheduling. The Sociological Quarterly, 52(3), 472-94.

Green, C. P., Heywood, J. S., Kler, P., \& Leeves, G. (2018), Paradox Lost: The Disappearing Female Job Satisfaction Premium. British Journal of Industrial Relations, 56(3), 484502.

Grönlund, A., \& Öun, I. (2018). The gender-job satisfaction paradox and the dual-earner society: Are women (still) making work-family trade-offs?. Work, 59(4), 535-545.

Gutek, B.A, Cohen, G., \& Tsui, A. (1996). Reactions to perceived sex discrimination. Human relations, 49, 791-813.

Hauret, L., \& Williams, D.R. (2017). Cross-National Analysis of Gender Differences in Job Satisfaction. Industrial Relations, 56(2), 203-235.

Hundley, J. (2001). Why and When Are the Self-Employed More Satisfied with Their Work?. Industrial Relations, 40(2), 293-316.

Kaiser, L. C. (2007). Gender-job satisfaction differences across Europe. International Journal of Manpower, 28(1), 75-94.

Kim, S. (2005). Gender differences in the job satisfaction of public employees: A study of Seoul metropolitan government, Korea. Sex Roles, 52, 667-681.

Konrad, A., Corrigall, E., Lieb, P., \& Ritchie, J. (2000). Sex differences in job attribute preferences among managers and business students. Group and Organization Management, 25, 108-131.

Linz, S., \& Semykina, A. (2013), Job satisfaction, expectations, and gender: Beyond the European Union. International Journal of Manpower, 34(6), 584-615.

Long, J. E. (2005). The effects of tastes and motivation on individual income. Industrial and Labor Relations, 48(2), 338-351.

Lup, D. (2018). Something to celebrate (or not). The differing impact of promotion to manager on the job satisfaction of women and men. Work, employment and Society, 32(2), 407425.

Madden, J. (1985). The Persistence of Pay Differentials: The Economics of Sex Discrimination. in Women and Work, Vol. 1, edited by L. Larwood, A. H. Stromberg, and B. A. Gutek.,Beverly Hills, Sage, 76-114.

Mandel, H., \& Semyonov, M. (2006). A welfare state paradox: State interventions and women's employment opportunities in 22 countries. American Journal of Sociology, 111(6), 191049.

Mora, T., \& Ferrer-i-Carbonell, A. (2009). The job satisfaction gender gap among young recent universities graduates: Evidence for Catalonia. The Journal of Social-Economics, 38, 581-589.

Mueller, C., \& Kim, S. (2008). The contented female worker: Still a paradox?. Advances in Group Processes, 25, 117-149.

Perugini, C., \& Vladisavljević, M. (2019). Gender inequality and the gender-job satisfaction paradox in Europe. Labour Economics, 60, 129-147. 
Pinquart, M., \& Sorensen, S. (2000). Influences of socioeconomic status, social network, and competence on subjective well-being in later life: A meta-analysis. Psychology and Aging, 15(2), 187-224.

Rica (de la), S., Dolado, J. J., \& Llorens, V. (2005). Ceiling and Floors. Gender Wage Gaps by Education in Spain. IZA Discussion Paper, No. 1483.

Rico Belda, P. (2012). Satisfacción laboral de los asalariados en España. Revista de métodos cuantitativos para la economía y la empresa, 14, 137-158.

Sánchez-Sánchez, N., \& Fernández, A.C. (2019). Is women's satisfaction higher than men's?: self-selection, expectations of utility function. Acta Aoeconomica, 69(2), 267-295.

Sánchez-Sánchez, N M, \& Fernández, A.C. (2020), Public Versus Private Job Satisfaction. Is there a Trade-off between Wages and Stability?. Public Organization Review, 472, https://doi.org/10.1007/s11115-020-00472-7.

Sánchez-Sanchez, N., \& Fernández, A.C. (2021). How gender-based disparities affect women's job satisfaction? Evidence from Euro-Area. Social Indicators Research, 1-29, DOI: 10.1007/s11205-021-02647-1

Sánchez-Sánchez, N., \& Ahn, N. (2018). Is job satisfaction of high-level managers and selfemployed more pro-cyclical than normal employees. International Journal of Manpower, 39(6), 800-8019.

Sarrió, M Ester Barberá, Amparo Ramos \& Carlos Candela (2002). Glass ceiling in the professional promotion of women. Revista de Psicología Social, 17(2), 167-182.

Scandura, T.A., \& Lankau M.J. (1997). Relations of gender, family responsibility and flexible hours to organizational commitment and job satisfaction. Journal of organizational behavior, 18, 377-391.

Schneck, S. (2014). Why the self-employed are happier: Evidence from 25 European countries, Journal of Business Research, 67, 1043-1048.

Singhapakdi, A., Sirgy, M.J., Lee, D.J, Senasu, K, Yu, G.B., \& Nisius A.M. (2014). Gender disparity in job satisfaction ow Western versu8s Asian managers. Journal of Business Research, 67, 1257-1266.

Skalli, A., Theodossiou, I., \& Vasileiou, E. (2008). Jobs as Lancaster goods: Facets of job satisfaction and overall job satisfaction. The Journal of Socio-Economics, 37(5), 19061920.

Sloane, P. J., \& Williams, H. (2000). Job satisfaction, comparison earnings and gender. Labour, 14(3), 473-501.

Sousa-Poza, A., \& Sousa-Poza, A.A. (2000a). Taking another look at the gender/job satisfaction paradox. Kyklos, 53, 135-52.

Sousa-Poza, \& Sousa-Poza, A.A. (2000b). Well-being at work: a cross national analysis of the levels and determinants of job satisfaction. Journal of Socio-Economics, 29, 517-538.

Sousa-Poza, A., \& Sousa-Poza, A.A. (2010), Gender differences in job satisfaction in Great Britain, 1991-2000: permanent or transitory. Applied Economic Letters, 10(11), 691-694.

Souza-Poza, A., \& Sousa-Poza A.A. (2007). The effect of job satisfaction on labour turnover by gender: An analysis for Switzerland. The Journal of Socio-Economics, 36, 895-913.

Trzcinski, E., \& Holst, E. (2011). Why men might "have it all" while women still have to choose between career and family in Germany. SOEP papers, 356.

Valentine, S.R. (2002). Men and Women Supervisor's Job responsibility, job satisfaction, and employee monitoring. Sex role, 45 (3/4), DOI:10.1023/A:1013549710711

Westover, J. (2012). The job satisfaction-gender paradox revisited: A cross-national look at gender differences in job satisfaction, 1989-2005. Journal of Global Responsibility, 3(2), 263-277. 


\section{Annex}

Table A1. Descriptive statistics

\begin{tabular}{|c|c|c|c|c|}
\hline & Definition & Measure & Mean & Std. Dev \\
\hline Job satisfaction & Subjective job satisfaction & 0 to 10 & 7.30 & 1.85 \\
\hline female & If individual is female & Dummy $0 / 1$ & 0.42 & 0.49 \\
\hline age30 & Age $<=30$ & Dummy $0 / 1$ & 0.17 & 0.37 \\
\hline age 40 & $30<$ Age $<=40$ & Dummy 0/1 & 0.29 & 0.45 \\
\hline age 50 & $40<$ age $<=50$ & Dummy 0/1 & 0.30 & 0.46 \\
\hline age 60 & $51<$ age $<=60$ & Dummy 0/1 & 0.19 & 0.4 \\
\hline age 65 & $60<$ age $<=65$ & Dummy $0 / 1$ & 0.04 & 0.2 \\
\hline partner & If the individual is married or cohabiting & Dummy $0 / 1$ & 0.67 & 0.47 \\
\hline children & If the individual has children & Dummy $0 / 1$ & 0.35 & 0.47 \\
\hline n.children & Number of children & Number (0-5) & 0.39 & 0.64 \\
\hline educ1 & No education & Dummy 0/1 & 0.03 & 0.18 \\
\hline educ2 & Maximum education primary & Dummy $0 / 1$ & 0.17 & 0.37 \\
\hline educ3 & Maximum education secondary & Dummy $0 / 1$ & 0.21 & 0.41 \\
\hline educ4 & Maximum education high-school & Dummy $0 / 1$ & 0.34 & 0.47 \\
\hline educ5 & Maximum education University & Dummy $0 / 1$ & 0.25 & 0.43 \\
\hline ocup1 & Directors and Managers & Dummy $0 / 1$ & 0.07 & 0.26 \\
\hline ocup2 & Scientific and intellectual technicians & Dummy $0 / 1$ & 0.14 & 0.35 \\
\hline ocup3 & Technicians & Dummy 0/1 & 0.14 & 0.35 \\
\hline ocup4 & Accounting, administrative & Dummy $0 / 1$ & 0.07 & 0.26 \\
\hline ocup5 & Customer services clerks & Dummy $0 / 1$ & 0.16 & 0.36 \\
\hline ocup6 & Skilled agricultural, fishery workers & Dummy $0 / 1$ & 0.04 & 0.19 \\
\hline ocup7 & Skilled manufacturing industry workers & Dummy $0 / 1$ & 0.22 & 0.41 \\
\hline ocup8 & Food, tobacco and textile workers & Dummy $0 / 1$ & 0.03 & 0.17 \\
\hline ocup9 & Elementary occupations & Dummy $0 / 1$ & 0.12 & 0.32 \\
\hline ocup10 & Armed forces occupations & Dummy $0 / 1$ & 0.00 & 0.06 \\
\hline seniority & Work experience & Years & 12.80 & 10.7 \\
\hline lowwage & If wages is below 1200 & Dummy $0 / 1$ & 0.29 & 0.45 \\
\hline mediumwage & $1201<$ wages $<=3000$ & Dummy 0/1 & 0.50 & 0.5 \\
\hline highwage & Wages $>3001$ & Dummy $0 / 1$ & 0.13 & 0.34 \\
\hline lowwagehouse & If house wages is below 1200 & Dummy $0 / 1$ & 0.12 & 0.33 \\
\hline mediumwagehouse & $1201<$ house wages $<=3000$ & Dummy $0 / 1$ & 0.54 & 0.49 \\
\hline highwagehouse & House wages >3001 & Dummy $0 / 1$ & 0.29 & 0.45 \\
\hline self-employed without & Self-employed without employees & Dummy $0 / 1$ & 0.13 & 0.34 \\
\hline self-employed with & Self-employed with employees & Dummy $0 / 1$ & 0.05 & 0.22 \\
\hline Low manager & If individual is manager & Dummy $0 / 1$ & 0.15 & 0.36 \\
\hline High manager & If individual is high manager & Dummy $0 / 1$ & 0.02 & 0.13 \\
\hline Inhours & Hours worked & Ln hours & 3.64 & 0.33 \\
\hline night & If individual works at night & Dummy $0 / 1$ & 0.14 & 0.34 \\
\hline turn & If individual works by turns & Dummy 0/1 & 0.17 & 0.37 \\
\hline temporary & If individual holds temporal contract & Dummy $0 / 1$ & 0.19 & 0.40 \\
\hline public & If individual works in public sector & Dummy $0 / 1$ & 0.20 & 0.40 \\
\hline partial & If individual holds part-time job & Dummy $0 / 1$ & 0.13 & 0.34 \\
\hline region1 & Andalucia & Dummy 0/1 & 0.09 & 0.28 \\
\hline region2 & Aragon & Dummy $0 / 1$ & 0.04 & 0.19 \\
\hline region3 & Asturias & Dummy 0/1 & 0.03 & 0.18 \\
\hline region4 & Baleares & Dummy 0/1 & 0.03 & 0.18 \\
\hline region5 & Canarias & Dummy $0 / 1$ & 0.04 & 0.19 \\
\hline region6 & Cantabria & Dummy 0/1 & 0.03 & 0.16 \\
\hline region7 & Castilla-leon & Dummy $0 / 1$ & 0.05 & 0.21 \\
\hline region8 & Castilla la mancha & Dummy $0 / 1$ & 0.04 & 0.19 \\
\hline region9 & Cataluña & Dummy $0 / 1$ & 0.26 & 0.44 \\
\hline region10 & C. valenciana & Dummy 0/1 & 0.07 & 0.26 \\
\hline region11 & Extremadura & Dummy $0 / 1$ & 0.03 & 0.17 \\
\hline region12 & Galicia & Dummy 0/1 & 0.05 & 0.22 \\
\hline region13 & Madrid & Dummy $0 / 1$ & 0.10 & 0.30 \\
\hline region14 & Murcia & Dummy 0/1 & 0.03 & 0.18 \\
\hline region15 & Navarra & Dummy $0 / 1$ & 0.03 & 0.17 \\
\hline region16 & País Vasco & Dummy 0/1 & 0.05 & 0.21 \\
\hline region17 & La Rioja & Dummy $0 / 1$ & 0.02 & 0.15 \\
\hline Continuoushours & Continuous working hours & Dummy 0/1 & 0.53 & 0.49 \\
\hline Sunday & If individual works on Sunday & Dummy 0/1 & 0.06 & 0.24 \\
\hline Hours $>8$ & If individual works more than 8 hours & Dummy $0 / 1$ & 0.28 & 0.45 \\
\hline Observations & & & 30882 & \\
\hline
\end{tabular}

Note: The variables in bold are the categories of reference in the estimations. 
RECENT ISSUES IN SOCIOLOGICAL RESEARCH

Table A2. OLS Estimation Results on Job Satisfaction (Complete Results of Table 4)

\begin{tabular}{|c|c|c|}
\hline & Coefficient & $\mathrm{p}$ value \\
\hline female & 0.12 & 0.02 \\
\hline age 40 & -0.03 & 0.68 \\
\hline age 50 & -0.08 & 0.23 \\
\hline age 60 & -0.10 & 0.30 \\
\hline age 65 & 0.39 & 0.01 \\
\hline partner & -0.01 & 0.89 \\
\hline children & -0.15 & 0.01 \\
\hline nchildren & 0.04 & 0.19 \\
\hline educ2 & -0.02 & 0.88 \\
\hline educ3 & -0.30 & 0.79 \\
\hline educ4 & -0.20 & 0.11 \\
\hline educ5 & -0.41 & 0.00 \\
\hline ocup1 & 0.41 & 0.00 \\
\hline ocup2 & 0.59 & 0.00 \\
\hline ocup3 & 0.42 & 0.00 \\
\hline ocup4 & 0.23 & 0.01 \\
\hline ocup5 & 0.32 & 0.00 \\
\hline ocup6 & -0.03 & 0.84 \\
\hline ocup7 & 0.06 & 0.41 \\
\hline ocup8 & 0.01 & 0.94 \\
\hline ocup10 & -0.26 & 0.35 \\
\hline seniority & -0.01 & 0.00 \\
\hline lowwage & 0.19 & 0.05 \\
\hline mediumwage & 0.45 & 0.00 \\
\hline highwage & 0.64 & 0.00 \\
\hline lowwagehouse & 0.21 & 0.18 \\
\hline mediumwagehouse & 0.25 & 0.00 \\
\hline highwagehouse & 0.51 & 0.00 \\
\hline Low manager & 0.33 & 0.00 \\
\hline High manager & 0.65 & 0.00 \\
\hline Self-employed without & 0.11 & 0.24 \\
\hline Self-employed with & 0.68 & 0.00 \\
\hline Self-employed without female & 0.02 & 0.89 \\
\hline Self-employed with female & 0.10 & 0.87 \\
\hline Low manager female & -0.24 & 0.01 \\
\hline High manager female & -0.20 & 0.18 \\
\hline lnhours & -0.24 & 0.01 \\
\hline night & 0.10 & 0.06 \\
\hline turn & 0.05 & 0.33 \\
\hline mashours & -0.01 & 0.01 \\
\hline temporary & -0.29 & 0.00 \\
\hline public & 0.17 & 0.00 \\
\hline partial & -0.06 & 0.39 \\
\hline continoushours & -0.09 & 0.02 \\
\hline Sunday & -0.30 & 0.00 \\
\hline Hours $>8$ & -0.14 & 0.01 \\
\hline const & 7.48 & 0.00 \\
\hline
\end{tabular}

Note: The categories of reference are: age30 ( $<30$ years), educ1 (without studies), ocup9 (semiskilled workers), minimum wage. Regions is a control variable but are not showed in the table to avoid so much data. 
Table A3. OLS Estimation Results on Job Satisfaction with different domains (complete results of Tables 5, 6 and 7)

\begin{tabular}{|c|c|c|c|c|c|c|c|c|c|c|c|c|c|c|}
\hline & \multicolumn{2}{|c|}{ Wage } & \multicolumn{2}{|c|}{ Promotion } & \multicolumn{2}{|c|}{ Work hours } & \multicolumn{2}{|c|}{ Flexibility } & \multicolumn{2}{|c|}{ Job Stability } & \multicolumn{2}{|c|}{ Job Stress } & \multicolumn{2}{|c|}{ Evironment } \\
\hline & Coef. & $\mathrm{p}$ value & Coef. & $\mathrm{p}$ value & Coef. & $\mathrm{p}$ value & Coef. & $\mathrm{p}$ value & Coef. & $\mathrm{p}$ value & Coef. & $p$ value & Coef. & p value \\
\hline female & 0.28 & 0.00 & -0.27 & $\overline{0.01}$ & 0.01 & 0.92 & -0.21 & 0.01 & 0.04 & 0.57 & 0.60 & 0.00 & 0.01 & 0.94 \\
\hline age 40 & -0.22 & 0.00 & -0.49 & 0.00 & 0.03 & 0.67 & 0.00 & 0.98 & -0.20 & 0.03 & 0.29 & 0.01 & -0.26 & 0.01 \\
\hline age 50 & -0.27 & 0.00 & -0.65 & 0.00 & 0.03 & 0.75 & 0.06 & 0.56 & -0.21 & 0.02 & 0.16 & 0.15 & -0.16 & 0.12 \\
\hline age 60 & -0.30 & 0.00 & -1.30 & 0.00 & 0.23 & 0.04 & -0.06 & 0.68 & -0.36 & 0.00 & -0.21 & 0.15 & -0.21 & 0.11 \\
\hline age 65 & -0.33 & 0.17 & -0.94 & 0.01 & 0.53 & 0.01 & 0.76 & 0.00 & -0.12 & 0.59 & -0.80 & 0.01 & 0.29 & 0.10 \\
\hline partner & -0.05 & 0.52 & -0.09 & 0.42 & -0.05 & 0.45 & -0.04 & 0.69 & -0.09 & 0.25 & 0.16 & 0.09 & -0.11 & 0.20 \\
\hline children & -0.53 & 0.00 & -0.38 & 0.00 & 0.30 & 0.00 & 0.04 & 0.71 & -0.15 & 0.06 & -0.21 & 0.03 & -0.11 & 0.23 \\
\hline nchildren & 0.18 & 0.00 & -0.01 & 0.89 & -0.12 & 0.01 & 0.08 & 0.15 & 0.01 & 0.87 & 0.00 & 0.94 & 0.05 & 0.27 \\
\hline educ2 & -0.04 & 0.79 & -0.41 & 0.09 & 0.32 & 0.02 & 0.37 & 0.04 & 0.10 & 0.52 & 0.05 & 0.80 & -0.07 & 0.67 \\
\hline educ3 & 0.05 & 0.75 & -0.42 & 0.08 & 0.36 & 0.01 & 0.47 & 0.01 & 0.27 & 0.07 & -0.12 & 0.53 & 0.00 & 0.98 \\
\hline educ4 & -0.10 & 0.49 & -0.61 & 0.01 & 0.22 & 0.11 & 0.33 & 0.06 & 0.08 & 0.61 & 0.23 & 0.23 & -0.14 & 0.40 \\
\hline educ5 & -0.12 & 0.45 & -0.65 & 0.01 & -0.02 & 0.92 & 0.17 & 0.36 & 0.11 & 0.48 & 0.22 & 0.27 & -0.26 & 0.13 \\
\hline ocup1 & 0.43 & 0.00 & 0.69 & 0.00 & 0.30 & 0.02 & 0.28 & 0.06 & 0.28 & 0.05 & 0.77 & 0.00 & 0.21 & 0.25 \\
\hline ocup2 & 0.36 & 0.00 & 0.32 & 0.09 & 0.40 & 0.00 & 0.13 & 0.37 & 0.10 & 0.51 & 0.93 & 0.00 & 0.42 & 0.01 \\
\hline ocup3 & 0.26 & 0.01 & 0.57 & 0.00 & 0.36 & 0.00 & 0.37 & 0.00 & 0.25 & 0.02 & 0.79 & 0.00 & 0.40 & 0.01 \\
\hline ocup4 & 0.22 & 0.03 & 0.50 & 0.00 & 0.39 & 0.00 & 0.20 & 0.14 & 0.30 & 0.01 & 0.74 & 0.00 & 0.16 & 0.34 \\
\hline ocup5 & 0.20 & 0.04 & 0.76 & 0.00 & 0.13 & 0.18 & -0.16 & 0.15 & 0.43 & 0.00 & 0.69 & 0.00 & 0.34 & 0.02 \\
\hline ocup6 & -0.16 & 0.27 & -0.08 & 0.80 & 0.28 & 0.07 & 0.08 & 0.68 & 0.01 & 0.96 & -0.12 & 0.58 & 0.23 & 0.34 \\
\hline ocup7 & 0.10 & 0.25 & 0.06 & 0.67 & 0.15 & 0.09 & -0.33 & 0.00 & -0.09 & 0.35 & 0.64 & 0.00 & 0.13 & 0.32 \\
\hline ocup8 & 0.09 & 0.51 & -0.18 & 0.46 & 0.24 & 0.07 & -0.24 & 0.20 & 0.03 & 0.86 & 0.51 & 0.01 & 0.08 & 0.64 \\
\hline ocup10 & -0.45 & 0.10 & 0.41 & 0.42 & -0.06 & 0.89 & -0.91 & 0.08 & -0.82 & 0.24 & -0.32 & 0.64 & 0.47 & 0.18 \\
\hline seniority & 0.00 & 0.16 & -0.01 & 0.06 & -0.01 & 0.00 & -0.02 & 0.00 & 0.02 & 0.00 & 0.02 & 0.00 & -0.02 & 0.00 \\
\hline lowwage & 0.47 & 0.00 & 0.67 & 0.00 & 0.51 & 0.00 & -0.06 & 0.71 & 0.23 & 0.07 & 0.37 & 0.02 & 0.00 & 1.00 \\
\hline mediumwage & 1.41 & 0.00 & 1.20 & 0.00 & 0.65 & 0.00 & 0.01 & 0.95 & 0.50 & 0.00 & 0.44 & 0.01 & 0.06 & 0.73 \\
\hline highwage & 2.02 & 0.00 & 1.58 & 0.00 & 0.79 & 0.00 & -0.01 & 0.94 & 0.76 & 0.00 & 0.42 & 0.03 & 0.29 & 0.19 \\
\hline lowwagehouse & 0.48 & 0.02 & 0.40 & 0.25 & 0.14 & 0.49 & 0.35 & 0.16 & 0.70 & 0.00 & -0.44 & 0.11 & 0.04 & 0.89 \\
\hline mediumwagehouse & 0.66 & 0.00 & 0.44 & 0.21 & 0.28 & 0.17 & 0.45 & 0.06 & 1.02 & 0.00 & -0.43 & 0.11 & 0.17 & 0.56 \\
\hline highwagehouse & 0.77 & 0.00 & 0.35 & 0.32 & 0.35 & 0.10 & 0.44 & 0.08 & 1.07 & 0.00 & -0.25 & 0.35 & 0.07 & 0.81 \\
\hline Self-employed without & -0.06 & 0.56 & 0.22 & 0.50 & 0.02 & 0.82 & 0.99 & 0.00 & -1.19 & 0.00 & 0.23 & 0.09 & -0.25 & 0.34 \\
\hline Self-employed with & 0.26 & 0.48 & 2.46 & 0.00 & -0.02 & 0.97 & 1.04 & 0.02 & -0.32 & 0.42 & 0.43 & 0.38 & -0.24 & 0.72 \\
\hline Low manager & 0.36 & 0.00 & 0.96 & 0.00 & 0.15 & 0.03 & 0.51 & 0.00 & 0.29 & 0.00 & 0.61 & 0.00 & 0.26 & 0.00 \\
\hline High manager & 0.51 & 0.00 & 1.77 & 0.00 & 0.17 & 0.14 & 1.02 & 0.00 & -0.16 & 0.17 & 0.87 & 0.00 & 0.74 & 0.00 \\
\hline High manager female & -0.33 & 0.05 & -0.11 & 0.78 & 0.16 & 0.40 & 0.06 & 0.78 & -0.03 & 0.86 & -0.39 & 0.08 & 0.08 & 0.72 \\
\hline Low manager female & -0.28 & 0.02 & -0.60 & 0.04 & -0.29 & 0.07 & 0.00 & 0.99 & -0.48 & 0.13 & -0.13 & 0.39 & -0.17 & 0.27 \\
\hline Self-employed with & 1.15 & 0.08 & -2.53 & 0.17 & -0.45 & 0.58 & -0.44 & 0.71 & 0.36 & 0.59 & -0.23 & 0.77 & -1.78 & 0.46 \\
\hline Self-employed & -0.31 & 0.07 & -0.58 & 0.31 & 0.11 & 0.52 & -0.04 & 0.86 & 0.26 & 0.19 & -0.20 & 0.39 & 0.78 & 0.02 \\
\hline lnhours & -0.31 & 0.00 & -0.34 & 0.12 & -0.43 & 0.00 & -0.21 & 0.14 & -0.21 & 0.08 & 0.54 & 0.00 & -0.43 & 0.00 \\
\hline night & 0.11 & 0.10 & -0.12 & 0.30 & 0.59 & 0.00 & 0.43 & 0.00 & 0.15 & 0.04 & -0.27 & 0.00 & 0.12 & 0.24 \\
\hline turn & -0.03 & 0.67 & -0.18 & 0.08 & 0.04 & 0.57 & 0.00 & 0.99 & 0.07 & 0.31 & -0.23 & 0.01 & 0.06 & 0.47 \\
\hline mashours & -0.04 & 0.00 & 0.02 & 0.11 & -0.05 & 0.00 & -0.03 & 0.00 & -0.04 & 0.00 & 0.10 & 0.00 & -0.03 & 0.00 \\
\hline temporary & -0.06 & 0.35 & -0.46 & 0.00 & -0.12 & 0.05 & -0.43 & 0.00 & -2.26 & 0.00 & -0.34 & 0.00 & -0.25 & 0.00 \\
\hline public & -0.01 & 0.81 & 0.17 & 0.07 & 0.33 & 0.00 & 0.00 & 0.97 & 0.46 & 0.00 & -0.06 & 0.41 & 0.06 & 0.38 \\
\hline partial & 0.13 & 0.11 & -0.23 & 0.09 & -0.03 & 0.75 & 0.35 & 0.00 & -0.07 & 0.46 & -0.09 & 0.42 & -0.09 & 0.39 \\
\hline continoushours & -0.09 & 0.06 & -0.20 & 0.01 & 0.61 & 0.00 & 0.09 & 0.14 & -0.08 & 0.18 & 0.06 & 0.33 & -0.20 & 0.00 \\
\hline Sunday & -0.16 & 0.16 & -0.31 & 0.13 & -0.47 & 0.00 & -0.60 & 0.00 & -0.12 & 0.33 & -0.13 & 0.45 & -0.24 & 0.40 \\
\hline Hours $>8$ & -0.04 & 0.45 & -0.19 & 0.09 & -0.81 & 0.00 & -0.51 & 0.00 & -0.20 & 0.02 & 0.34 & 0.00 & -0.06 & 0.40 \\
\hline const & 5.94 & 0.00 & 6.14 & 0.00 & 6.16 & 0.00 & 5.89 & 0.00 & 6.69 & 0.00 & 2.67 & 0.00 & 9.53 & 0.00 \\
\hline
\end{tabular}

Note: The categories of reference are: age30 ( $<30$ years), educ1 (without studies), ocup9 (semiskilled workers), minimum wage. Regions is a control variable but are not showed in the table to avoid so much data. 